\title{
Reconstructing Hilandar Monastery 2004-09: the first phase
}

\author{
P. M. Milojevic \\ School of Architecture and Planning, University of Auckland, \\ New Zealand
}

\begin{abstract}
The catastrophic fire that struck the continuously-inhabited Middle Byzantine Hilandar Monastery, the Imperial Serbian Lavra of the Most Holy Mother of God (Mount Athos, Greece) in March 2004 came, ironically, at the completion of the Serbian authorities' eighteen year conservation plan. Two 12th Century towers, acting as fire-breaks, saved the older south courtyard and katholikon from destruction, but more than half of the monastery's masonry and timber enclosure, 5761sqm, was lost. Major fires have periodically destroyed Athonite monasteries in whole or part, but Hilandar's will be the first wholesale reconstruction in the last century and is, thereby, an unprecedented situation in which a very significant proportion of a World Heritage Site is to be rebuilt anew within the minimal remaining standing masonry walls and substructures. The conservation works of the pre-fire era in the main walled enclosures towers, treasury, refectory, the largely abandoned Saint Basil monastery site, monastic port and hermitages generally set a standard to be emulated The stabilisation, protection and cleaning of the ruins began immediately and work is to be completed ca 2022. The first five year phase of the fire reinstatement of the intramural heritage structures, the focus of this paper, included the completion of: the porter's lodge/portarnice, St. Nicholas chapel/Paraklis Svetog Nikole, (1814), the Range/Konak (1814) and the shell of the 1816-1821 Range/Konak. This Serbian-Greek reinstatement/conservation project necessitates negotiating the balancing of support of the monastery's spiritual and daily life (i.e. rebuilding the destroyed administration offices, medical clinic etc) and work and economy (i.e. bakery, painting restoration lab etc) relating to Hilandar's surviving spaces and moveable heritage, and long-term reinstatement of hostels, work and storage sheds needed in order to initiate this scale of heritage structure reinstatement. For over a century, until 2004, the expert supervision required to cope with the Hilandar's heritage came solely from religious and secular entities in Belgrade, but the extent and value of the recent loss triggered a new protocol led by the Thessaloniki-based Centre for Protection of the Heritage of the Holy Mountain and scrutinized by UNESCO and ICOMOS for 'this Serbian project in Greece'.
\end{abstract}

Keywords: architectural heritage, conservation, reconstruction, issues. 


\section{Destruction}

Six years after the celebrations around the 800th anniversary of its founding (Subotic [17]) the Imperial Serbian Lavra of the Most Holy Mother of God, Hilandar Monastery (Mount Athos, Macedonia, Greece), is now and has been for quite some time, the focus of considerable attention by philologists, historians, art and architectural historians (Fig.1). In Hilandar Monastery, the last-remaining Serbian monastic foundation of three on Athos, a fire on the night of the 3-4th of March 2004 destroyed approximately one half of the main building ensemble of this UNESCO World Heritage Site. This catastrophe struck towards the end of an eighteen year long phase of conservation and structural upgrading work of this architecturally-renowned continuously-inhabited walled enclosure comprising some 20,000 square metres of accommodation within the walls, gates and towers. The Saint Sava and Saint Demetrius towers to the northeast and northwest of the monastery church, from the earliest Serbian phase (Nenadovic [14]) of this building ensemble acted as fire-breaks against the huge conflagration from 'taking' the treasury, library, refectory, residential ranges and other communal facilities of the south courtyard. Emergency crews held the fire back from taking the 14th Century church, which is considered 'the finest on Athos' and certainly 'one of the finest Byzantine churches anywhere' (Mylonas [13]), the northwest corner of which was only eight meters from the four storey 13-14th Century Saint Demetrius towers which had caught fire first early that night and burned out completely. Aerial photographs taken in the first light of the morning shows the extent of damage (Fig 2). The timber fabric of the internal

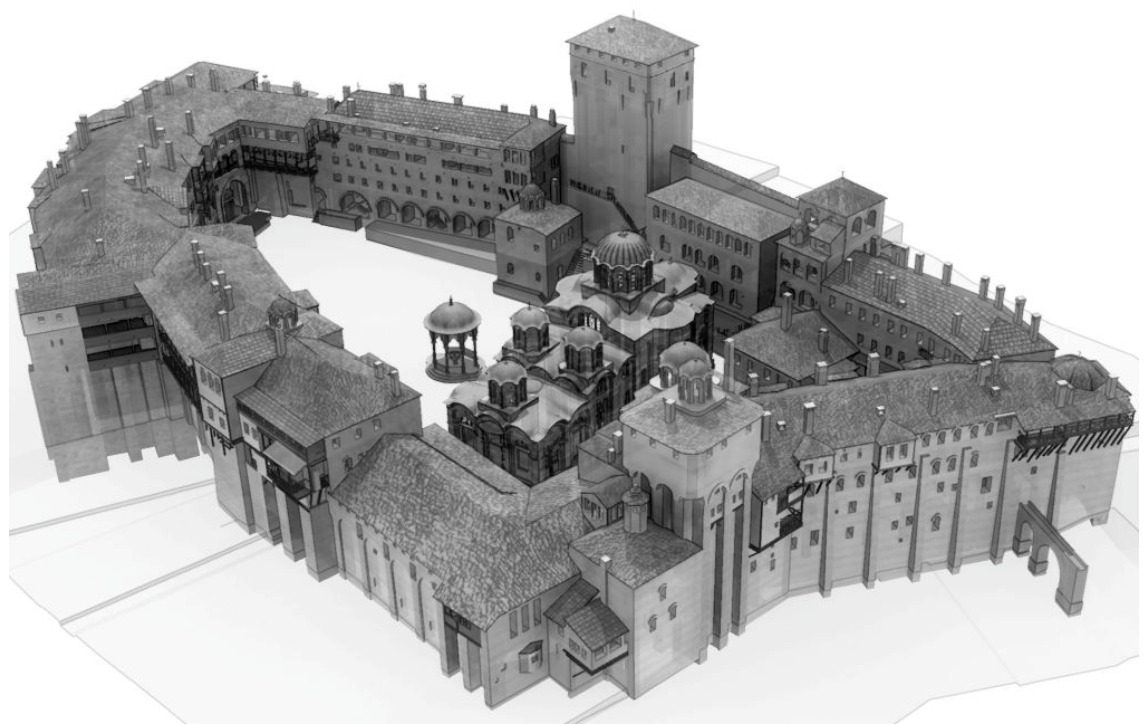

Figure 1: Hilandar Monastery, Mount Athos: digital model, render view from the southwest (Yat Wai Lo 2009). 


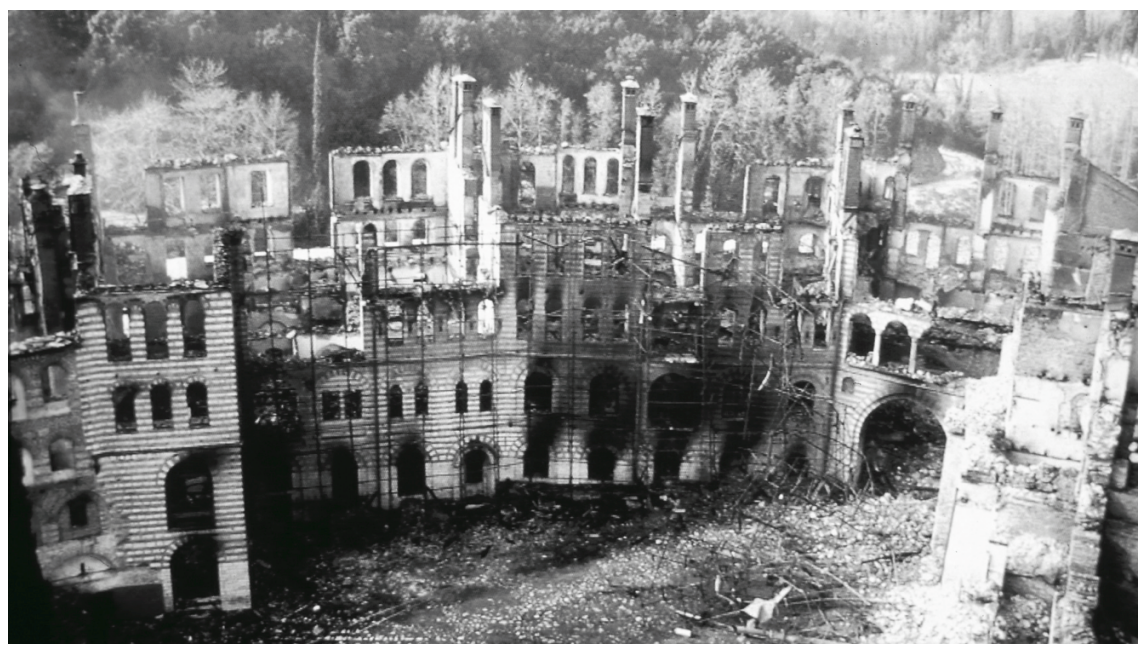

Figure 2: Hilandar Monastery, Mount Athos: north courtyard from the southeast top of Saint Sava tower (anon. 6 March 2004).

wall, floor and roof structure burned out such that the massive weight of the stone slab-tiled roofs collapsed such that the buildings collapsed into themselves; finally the lighter stone curtain walls fell. In all 15,000sqm of the 14-19th century fabric comprising residential ranges and four chapels was lost. Closely following on from the departure of the emergency crews, and the appearance of national and international VIPs, Athonite representatives, architectural conservators, arrived to direct emergency clean-up crews and assess the damage, along with building documentation specialists and so initiating the first wholesale rebuilding of an Athonite complex in Modern times. While the usual variety of reconstruction parameters has come up for consideration, including a definition of an exact description of the loss of unexpected opportunities and problems in the reconstruction have arisen. The particular (i.e. theological, cultural, architectural and financial) concerns and interests of, and complex interrelationship between, the small brotherhood of the monastery itself, and the four Serbian Belgrade-based bodies to whom the conservation architects Professor Mirko Kovacevic and Nenad Sekularac report (The Hilandar Foundation/Zaduzbina Svetog Manastira Hilandar, The Institute for the Protection of Cultural Monuments of the Republic of Serbia/Zavod za Zastitu Spomenika Kulture Republika Srbija [ZZSKRS], The Patriarchate of the Serbian Orthodox Church/Srpska Pravoslavne Patrijarsija, and the Serbian Ministry of Culture/Ministarstvo Kulture Republika Srbija) is negotiated with the Centre for

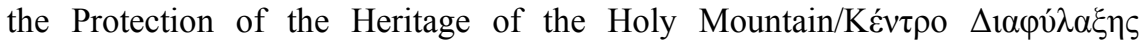

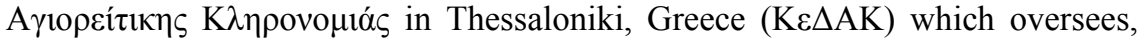
among other things, all building work on Athos regardless of whether the monastery is Greek, Russian, Bulgarian or Serbian. 


\section{Historical sources for reinstatement}

From a deep historical perspective, considering the fact that there have been, since the ninth century, many catastrophic fires on Athos, Hilandar's loss is not as bad as some, considering that it came at a time when a number of measured drawing and photographic documentation programs had just been completed (Boskovic and Kovacevic [2] and Korac and Kovacevic [7]); there is, incidentally, no archaeology as this is proscribed on Athos. Recent pre-fire conservation, for example of the late 16th Century White Range/Beli Konak and Library/Biblioteka, was based on the study of both the scant remains of the structure in situ as well as historical images (Milojevic [10]), which are of particular value for the building components dating since the 18th century, from when we have topographical and prospographic imprints that detail the buildings (Papstratou and Tavlakis [16]) as recently reviewed (Mylonas [13]). It is a particular misfortune then that what was certainly a very informative axonometric-type bird's-eye view of Hilandar by the early 18th Century monk and pilgrim, Vasilija Grigorovic Barskij has been lost (Barskij [1]), while we have only the related text Stranstrovanija (Grigorovich-Barskij [18]). While both before and after Barskij's important visual records were made of the monastery, none are as valuable as Zaharija Orfelin's 1779 detailed copperplate panorama of 1779 (Davidov [3]). Sustained scientific studies of the building fabric of the

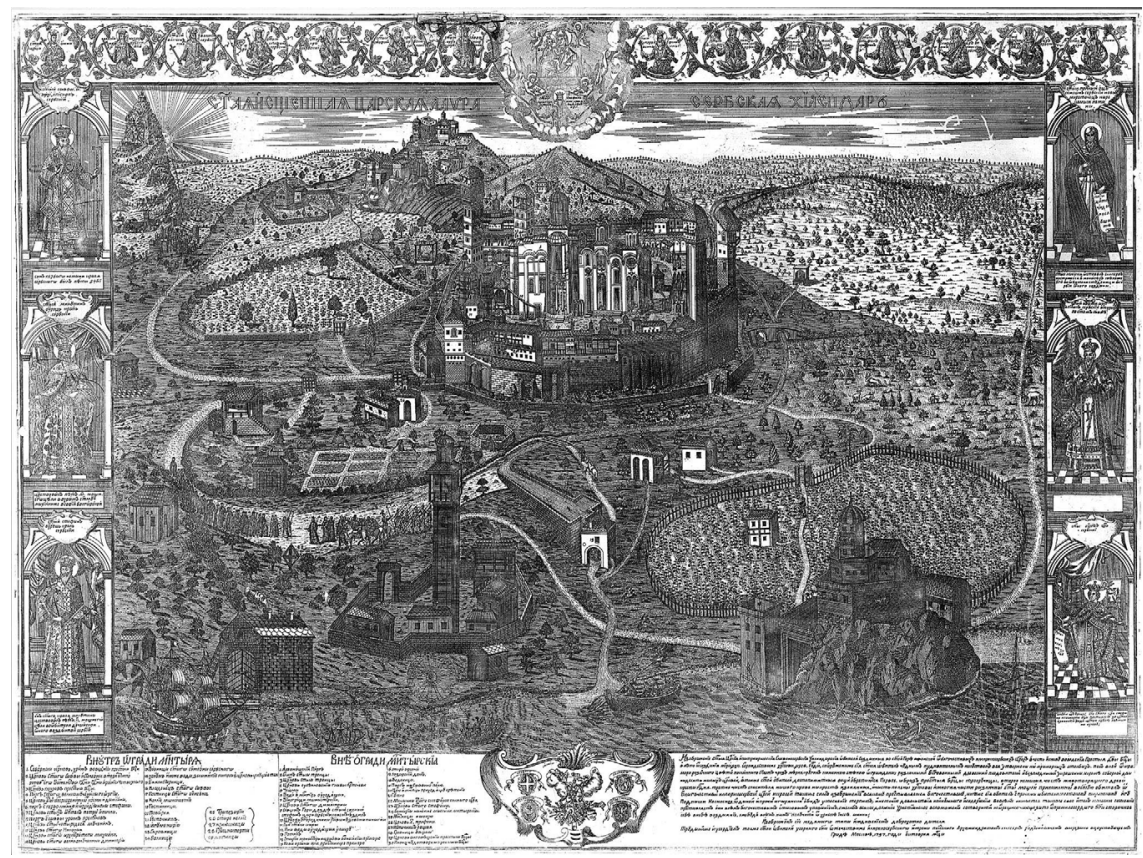

Figure 3: Hilandar Monastery, Mount Athos: anon. 1757, copper engraving (Digitalna Narodna Biblioteka Srbije). 
monastery were initiated in the 1920 s by Zarko Tatic for The Serbian Academy of Sciences and Arts/Srpska Akademija Nauka I Umetnosti and recommenced from the early 1960s by teams led by Boskovic, Deroko, Nenadovic and Subotic, coinciding with the launch of the scholarly journal Hilandarski Zbornik. Paralleling the complete microfiching of the library's manuscript collection by Matejic for the Ohio State University Hilandar Research Centre, the Institute for the Protection of Cultural Monuments conservation work (Medakovic [8]) led to the aforementioned international conference on the occasion of the 800th anniversary of Hilandar in 1989. Apart from the profusely illustrated editions summarising Hilandar's riches, new QTVR spherical imaging and digital modelling of the architecture have led the way in the interpretation of Athonite complexes (Hostetter [4] and Milojevic and Donovan [11]).

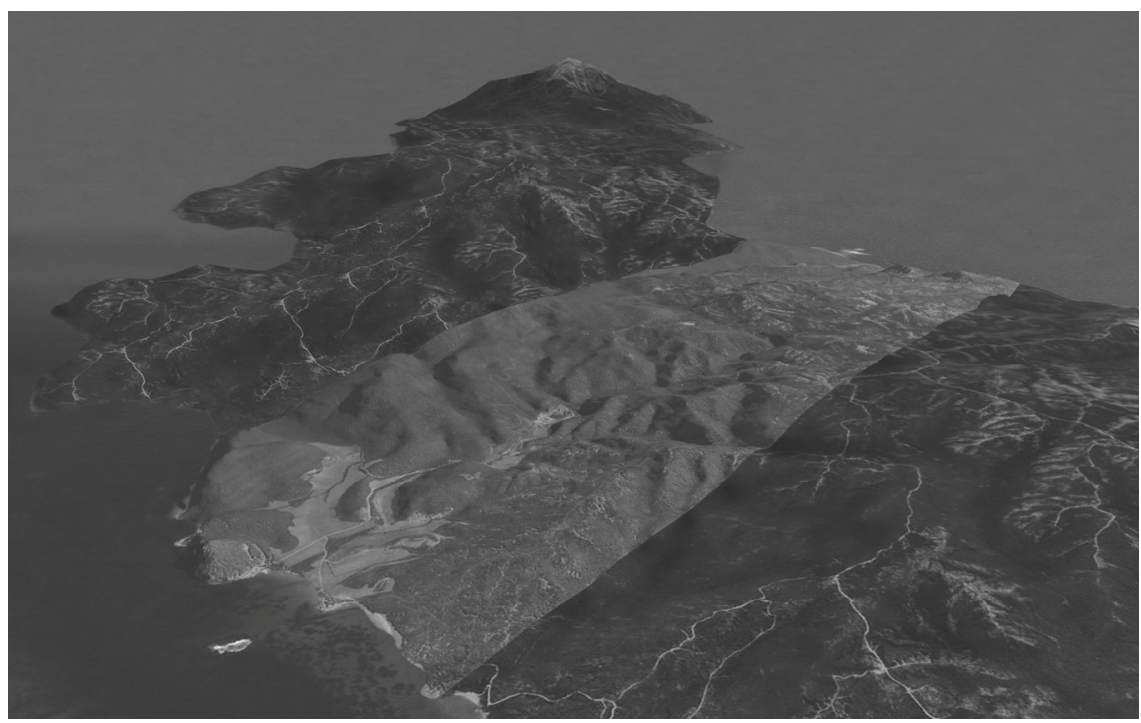

Figure 4: Hilandar Monastery, Mount Athos: oblique aerial view from the northeast, render from interactive digital relief map (Jun Ho Park 2009).

\section{Pre-fire conservation and structural upgrading}

While the maintenance and conservation of the building fabric had lapsed somewhat during much of the era leading up to and including Yugoslavia's Communist era since the early 1970s, the ZZSKRS developed a long term plan for the conservation of the architecture plan, addressing specific and urgent short- and long-term requirements. The most urgent of these was for improved security and environmental conditions for the internationally-important treasury and library (Karakatsanis [5]), which due to having been mistakenly constructed (Nenadovic [14]) with seawater in the mortar mix, brought damp stress to icons, 
vestments and liturgical items that had been relocated here for a short while. Among the next-most-urgent projects were the potentially disastrous instability of the six-story 12th Century Saint George/Pirg Svetog Djordje and Saint Sava/Pirg Svetog Save towers, and the 14th Century Milutin tower/Milutinova Kula, the seawall and the southeast wall of the 11th Century Saint Basil Monastery/Paraklis Svetog Vasilije Hrusija, and the esonarthex south facade vault arches of the 14th Century katholikon. Work of another kind was required in order to cope with the new approach for pilgrims from the peninsula's south side restoring the wharf and structures at the tiny dilapidated port/arcana of Govanitsa/Jovanica and more accommodation for construction teams at the Arsenica Metoh at Kakova just outside the Athos border near Ierrisos became a priority, as did arranging pilgrims' accommodation, the kitchen/hestia, refectory/trpezarija, reception house/gostionica and the 1816-1821 Range/Konak to cope with larger pilgrim numbers, which developed the monastery's income. The conservation of the 16th Century White Range/Beli Konak in 2002-2004, the last major stage of the long-term conservation plan for the main enclosure, was substantially complete and about to be handed over to the monks when the latest and most disastrous fire struck.

The ZZSKRS's conservation of the structural cracking and splitting of the massive stone and brick George, Sava and Milutin towers and the smaller, more structurally complex, katholikon and Saint Basil chapel/parekkleseion Svetog Vasilije in the Hrusija fortress, the most critical intervention involved stabilising the gradual and incremental vertical cracking and movement due to a

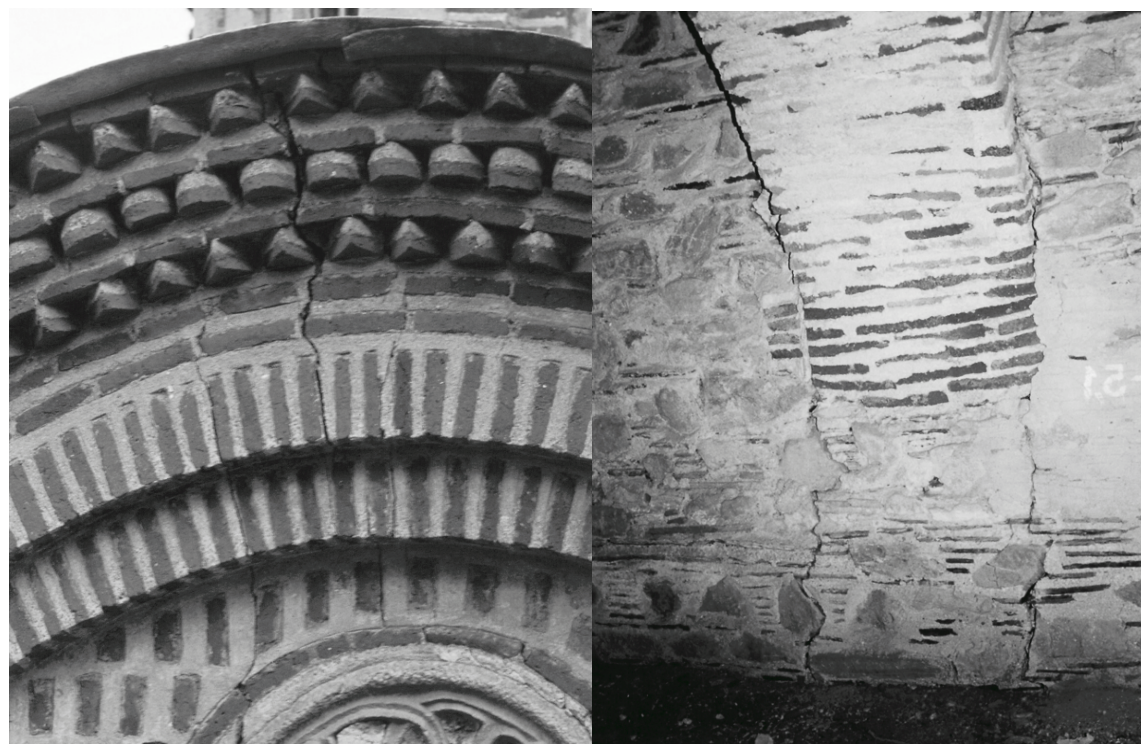

Figure 5: Hilandar Monastery, Mount Athos: cracking in cornice masonry of katholikon esonarthex, and cracking at base of diaphragm arch at ground level of Saint Sava tower (Kovacevic 1992). 


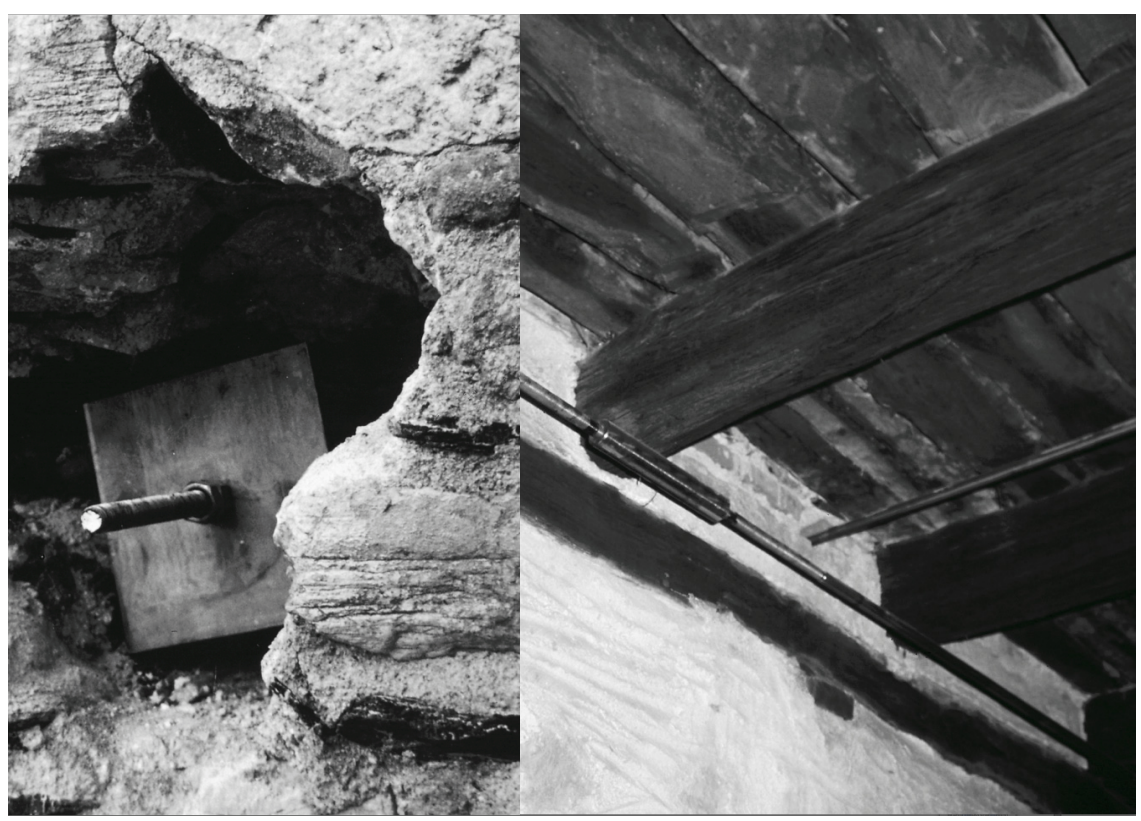

Figure 6: Hilandar Monastery, Mount Athos: Saint Sava tower, tie-rods wall anchoring and non-invasive positioning under floor (Kovacevic 1998 and 2000).

combination of the disintegration of the internal lateral timber floor and roof reinforcing and accumulated effects of water infiltration and seismic forces exacerbated by the considerable weight of the massive stone roofs in the case of the towers. Having, with Nenadovic, first employed a technique of consolidating and stabilising the building fabric of the Nova Pavlica Monastery katholikon near Brvenik in Serbia in the late 1980s using tie-rods and an injected binding agent, Kovacevic stabilised the five Hilandar structures using the same process of reinforcement and consolidation; the Demetrius tower in 1992-1993, the Milutin in 1995-1997, the Sava in 1999-2001 and the smaller ecclesiastical structures simultaneously. In all cases the cracking was 'stitched-up' by drilling diagonally through the mixed stone, brick and mortar wall fabric in both the horizontal and vertical axes and inserting a $20 \mathrm{~mm}$ diameter stainless steel tie-rod with tensioning sleeves (Fig 6, left) between and below the internal floor joists in both axes and inserting the anchor plates into the thickness of the wall (Fig 6, right) and masking these from view by burying them in the heavy external wall fabric and thus binding or reinforcing the external bearing wall structures of each of the towers levels by a horizontal and vertical matrix of tie-rods and plates steelwork. Subsequently, elasticised Pozzolana mortar was pressure injected into all of the internal wall voids through the major cracks and through new holes drilled (on a $50-60 \mathrm{~cm}$ grid) into the walls' vertical surface to access the internal voids. In the case of the Saint Basil chapel in the Hrusija fortress, the drilling for the tie-rods 


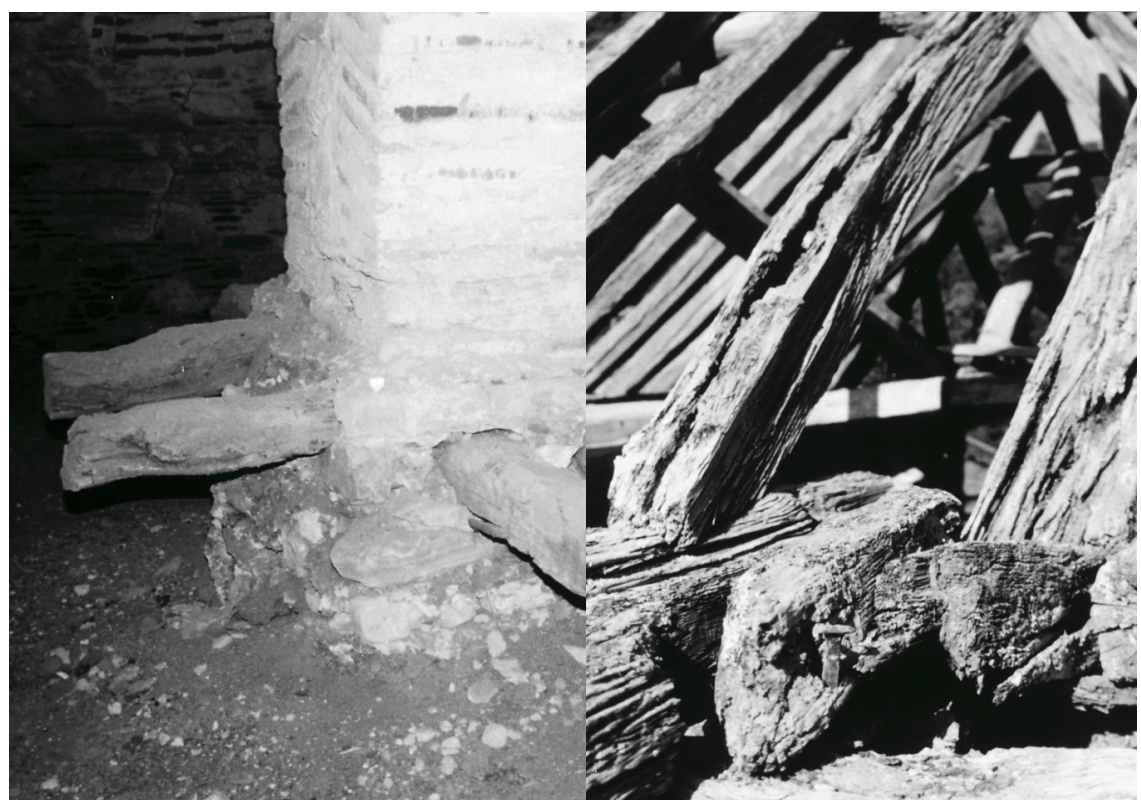

Figure 7: Hilandar Monastery, Mount Athos: Saint Sava tower, chestnut subfloor pier anchors and roof structure as found (Kovacevic 1997 and 1999).

were made in order to be able to anchor the chapel walls to the adjacent curtain wall of the fortress. In the case of the two towers, essential sub-structural and super-structural work involved renewing the chestnut timber rafters where rotting of individual members (Fig. 7, right) in the Sava tower had put strain on adjacent members to the point of an imminent failure of the entire roof structure (Nenadovic [15]), and the renewal of the chestnut anchor timbers in the pier foundations (Fig. 7, left). In the case of the penultimate level of both the George and Sava towers, reinforcing was anchored into a new concrete mass that replaces the pre-existing dry rubble fill found between the top of the vaulted ceiling structure of the floor below and the floor surface above in order to add structural cohesion in the event of powerful seismic activity.

\section{Post-fire stabilisation and reinstatement}

In the five years since the fire the work has progressed from stabilisation, cleaning and documentation in the first 18 months to completion of the first building component reinstatements. Given that the reinstatement may, for financial and procedural reasons, take 15 years to complete, the stabilisation has been engineered to the most current standards, which must withstand a seismic event of a significant magnitude and thus using steel members which, unfortunately, will be of no other value in the building work, rather than the 


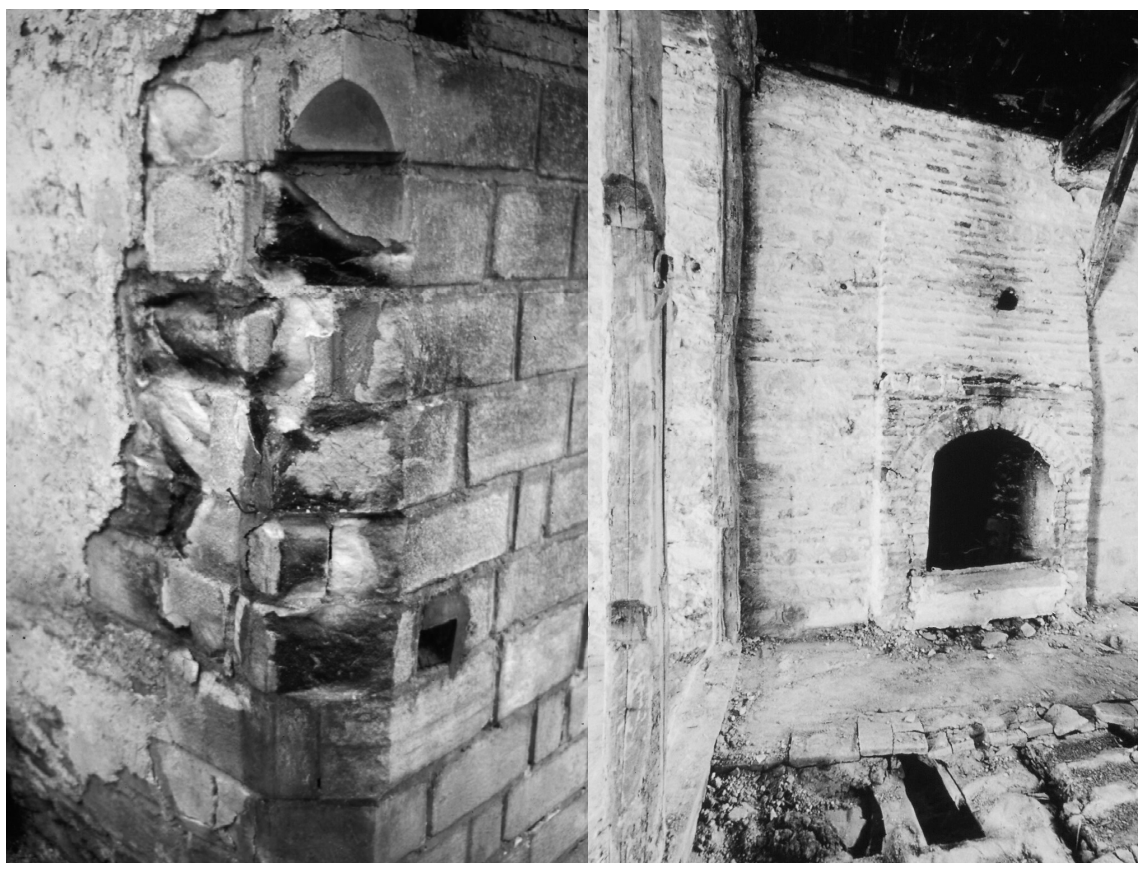

Figure 8: Hilandar Monastery, Mount Athos: 1816-1821 Range/Konak, ornamental corner detail and a hearth revealed by the fire destruction (Kovacevic 1997 and 1999).

heavy timber shoring that had been agreed on previous occasions for, say, the south wall of the Hrusija fortress. The imminent requirement for large timber members in the reinstatement prompted the cutting, at this time, of chestnut logs in Hilandar's 2000ha forest in order to be ready for sizing when the implications of the contemporary Greek building code on the burnt structures historic dimensioning becomes clear. With the burnt-out curtain wall building carcasses shored-up, the cleaning and documentation of the 1700sqm fire site recorded the new building information, such as hearths and ornamental masonry detail concealed by the later work and resurfacings that fell away in the destruction (Fig. 8). During this time the various secular and religious authorities and

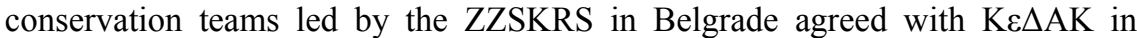
Thessaloniki and Greek building authorities on the financial and architectural scope of work of the first reinstatement projects of the estimated 15 year reinstatement plan. The 1814 Range, the smallest, most accessible, and in a sense the most discreet building element of the monastery's enclosure, immediately to the right side of the main gate, and the restructuring of the previously abandoned extramural hay loft/senara and stalls/stale just below the ramp up to the main enclosure for pilgrim accommodation, constituted the first projects of the first phase of the long-term plan. The extramural retrofit projects were completed in 


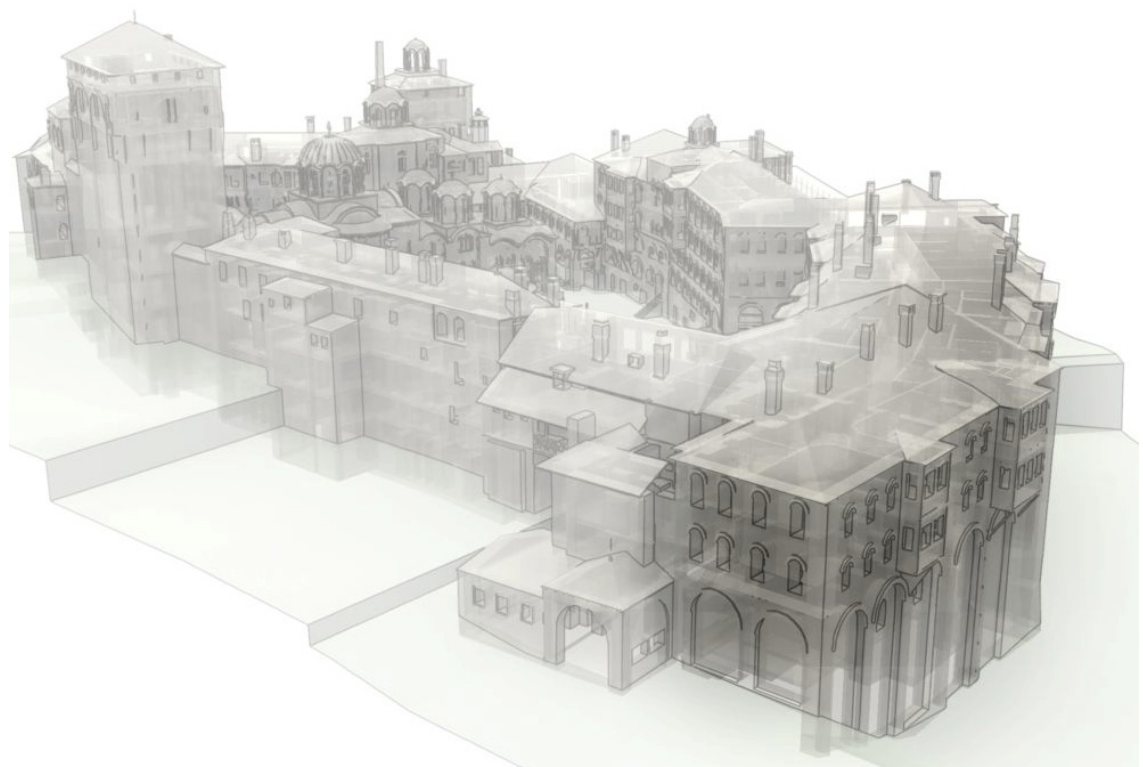

Figure 9: Hilandar Monastery, Mount Athos: digital model, view from north-east approach with the 1814 Range/Konak highlighted (Wai Yat Lo, 2009).

mid-2006 when the seven month long reinstatement project was begun on the three level 538sqm 1814 Range/Konak. While the synodal meeting room/sinodik on the top level and Bishop Melentija's cell/Kelija Vladika Melentije on the middle level are to retain their original usage, the exceptionally high ground level storeroom is to be the bookshop on the ground levels and gallery on the basement level. The reconstruction of this range involved the stabilisation of the large and unusual $13 \mathrm{~m}$ high central pier in the manner that the towers were reinforced in the 1990s. Currently the work at Hilandar is focussed on the reinstatement of the 1816-1821 Range/Konak, the monastery's largest (2724sqm) structure, which housed the reception/gostionica, administrative offices/kanslarije and conservation labs/konservatorske radionice and the majority of the guests' cells/kelije, started in October 2007 and currently is at about the mid-stage of its completion, which is due in early 2011. The exceptional weight of the collapsed stone slab roofs pulverised much of the stored marble refectory furniture, grain milling and printing equipment and wooden carts, resulting in the loss of a possible reinstatement of this area, which had been purpose-built as a donkey stall. In this range a fundamental conceptual question regarding reinstatement has emerged: whether some late 19th Century retrofitted iron reinforcing beams are now to be reinstated. That is, if one is to be regulated by the immediate pre-fire condition or rather to restore the structure to an original or other condition prior to pre-Modern and Modern upgrading work. 

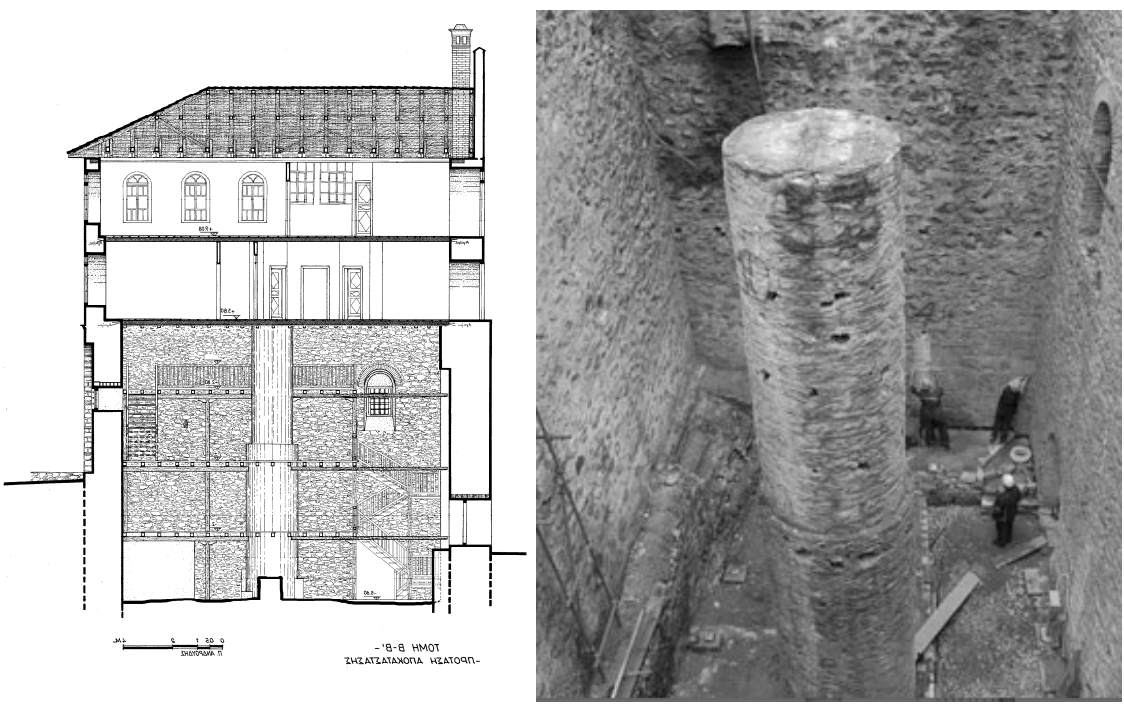

Figure 10: Hilandar Monastery, Mount Athos: 1816-1821 Range/Konak, section (Paraskevapoulos 2005) and the main pier (Kovacevic 2006).

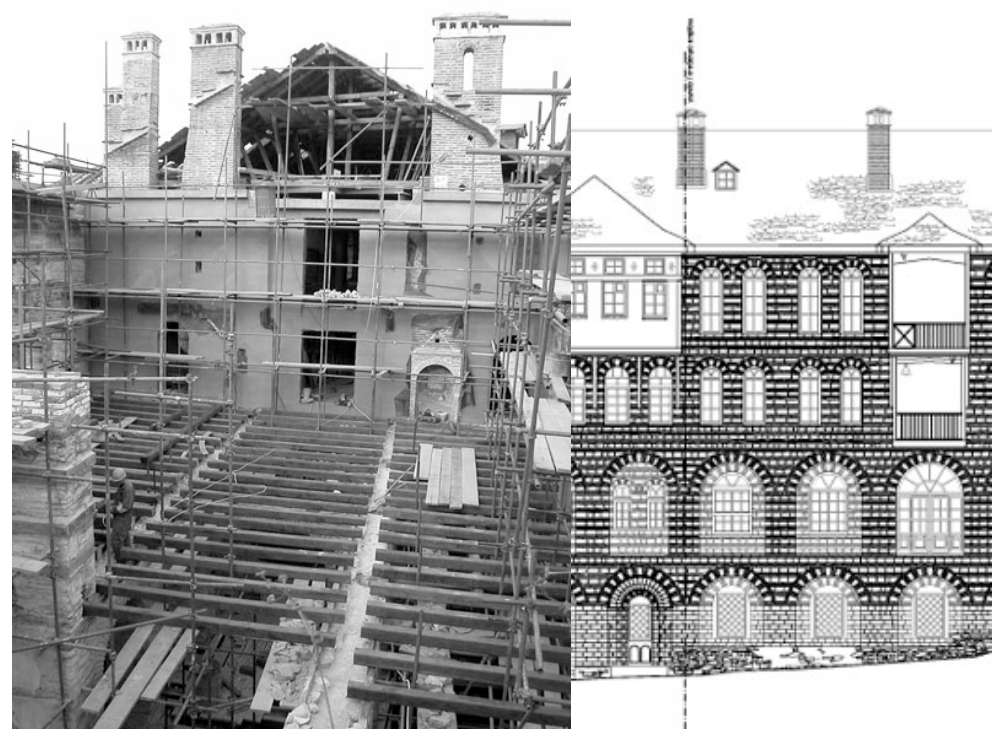

Figure 11: Hilandar Monastery, Mount Athos: 1816-1821 Range/Konak, section (Paraskevapoulos 2005) and the main pier (Kovacevic 2006). 


\section{Acknowledgements}

We wish to acknowledge the support of Father Metodija and the Holy Community of Hilandar. as well as the contributions of Professor Mirko Kovacevic, Jessica Lai, Adrian Lo, Shaylan Maharaj, Jun Ho Park, Andrew Smith and Adrianna Toader.

\section{References}

[1] Barskij, V.G., 1887. Stranstrovanija po svjatym' mestam Vostoka s'1723 po $1747 g$. St Peterburg vol I-IV.

[2] Boskovic, Djurdje en collaboration avec Mirko Kovacevic, 1992. Le monastere de Chilandar. Le catholicon. Architecture (Monuments de l'architecture medievale serbe. Institut pour la protection des monuments historiques de la Serbie). Beograd (Serbian and French texts).

[3] Davidov, Dinkov 1998. Hilandarske Grafike. Prosveta, Beograd.

[4] Hostetter, WM. T., 1998. U Crcy Hilandara / In the Heart of Hilandar. Belgrade (CD-ROM).

[5] Ieromonk Ioustinos Simonopetritis in Athanasios Karakatsanis, Karakatsanis, A. ed. 1997. Treasures of Mount Athos. Thessaloniki.

[6] Joint UNESCO/WHC-ICOMOS-IUCN Expert Mission Report Mount Athos 30 january-3 February 2006 (Paris 10 April 2006; tabled Vilnius 816 July 2006).

[7] Korac and Kovacevic, 2002. Le monastere de Chilandar. Les muirs et tours. Architecture. Beograd.

[8] Medakovic, Dejan 1978 (transl. Madge Philips-Tomasevic). 'The Study of Chilandar' in Bogdanovic, Dimitrije, Djuric, Vojislav and Medakovic, Dejan Chilandar. Beograd. pp. 197-203.

[9] Medjunaradni Kongres na Proslava 800 Godisnjice Manastira Hilandara Caopstenije, 1998 (International Conference on the Occasion of the 800th Anniversary of Hilandar Monastery 1198-1998, Proceedings, Serbian Academy of Sciences, Belgrade, 10-15 May 1998). Beograd.

[10] Milojevic, P.M. 2003. 'A Documentary QTVR Project at Hilandar Monastery', International Architecture Forum: Saving the World's Great Cities. (Saint Petersburg, 2003), pp 29-41.

[11] Milojevic, M. with B. Donovan, T. Hostetter and M. Kovacevic, Hilandar Panoramas. Hilandar Foundation Beograd, forthcoming 2009.

[12] Mylonas, P. M. 'A Short Appraisal of Vassilij Grigorovitch Barskij and his Travelogue', Zograf: Casopis za srednjovekovnu umetnost 26, 1997.

[13] Mylonas, P. M., 2000. Pictorial Dictionary of the Holy Mountain of Athos/Bildlexikon des Heiligen Berges Athos. Volume 1. Part 1 Atlas of the Twenty Sovereign Monasteries, Fascicule 1 Introductory Texts. Fascicule 2 The Atlas Photographic Documentation of Landscapes and Monasteries; Fascicule 3 The Atlas Maps and Plates. (Deutsches Archäologisches Institut). Tübingen. 
[14] Nenadovic, S M. 1997. Ocam Vekova Hilandara Gradjenje i Gradjevine. (in Cyrillic) Beograd.

[15] Nenadovic, S.M. 2003. Gradjevinska tehnika u srednjovekovnoj Srbiji. (in Cyrillic) Prosveta, Beograd.

[16] Papstratou, D. and Tavlakis, I, eds., 1997. Paper Ikons of Mount Athos. Thessaloniki.

[17] Subotic, Gojko, Manastir Hilandar Beograd, 1998 (in Cyrillic); the English edition: Gojko Subotic, ed., Radmila Popovic transl. Hilandar Monastery. Belgrade, 1998.

[18] Grigorovich-Barskij S.V., Stranstrovanija Vasilija Grigorovica-Barskago po svjatym mestam Vostoka s 1723 po 1747. Petersburg, 1814. 